\title{
Effect of Insecticidal Atmospheres at High Temperature Combined with Short Cold-quarantine Treatment on Quality of 'Valencia' Oranges
}

\author{
Adriana Contreras-Oliva
}

Centro de Tecnología Poscosecha, Instituto Valenciano de Investigaciones Agrarias, 46113 Moncada, Spain; and Campus Córdoba, Colegio de Postgraduados, Carretera Federal Córdoba-Veracrúz Km. 348, A.P. 94946 , Amatlán de los reyes, Veracrúz, México

\section{Cristina Rojas-Argudo}

Centro de Tecnología Poscosecha, Instituto Valenciano de Investigaciones Agrarias, 46113 Moncada, Spain

\section{María B. Pérez-Gago ${ }^{1}$}

Centro de Tecnología Poscosecha, Instituto Valenciano de Investigaciones Agrarias, 46113 Moncada, Spain; and Agroalimed, 46113 Moncada, Spain

Additional index words. Ceratitis capitata, controlled atmosphere, flavor, vitamin C, phenolics

Abstract. The combination of insecticidal atmosphere (IA) with short cold exposure periods has been effective in controlling the Mediterranean fruit fly, Ceratitis capitata (Wiedemann). In the present work, 'Valencia' orange quality was assessed on fruit exposed to IA $\left(95 \% \mathrm{CO}_{2}\right)$ at 23,28 , or $33{ }^{\circ} \mathrm{C}$ for $20 \mathrm{~h}$; next stored at $1{ }^{\circ} \mathrm{C}$ for 8,16 , or 24 days; and then kept at $20^{\circ} \mathrm{C}$ for 7 days to simulate shelf life. Physicochemical, sensory, and nutritional quality parameters were analyzed on treated and control (air-exposed) fruit. No significant negative effects on fruit quality were observed in IA-treated 'Valencia' oranges. In addition, the exposure of oranges to $95 \% \mathrm{CO}_{2}$ at $28{ }^{\circ} \mathrm{C}$ reduced the weight and firmness loss compared with fruit kept in air. Ethanol content increased in the fruits exposed to $95 \% \mathrm{CO}_{2}$ at 28 or $33{ }^{\circ} \mathrm{C}$, but sensory quality was not adversely affected.

Many countries maintain strict quarantine protocols against the Mediterranean fruit fly, Ceratitis capitata (Wiedemann) (Diptera: Tephritidae), which is one of the most damaging fruit pests worldwide and may be a major pest of citrus (White and Elson, 2004). The most widely used postharvest disinfestation treatment of citrus against this fruit fly involves exposure of the fruit to near freezing temperatures. In the United States, the U.S. Department of Agriculture established a minimum exposure during overseas transit of 14 to $18 \mathrm{~d}$ at 1.1 to $2.2^{\circ} \mathrm{C}$ (USDA, 2002). Today, extensive research is currently focused on the development of alternative or complementary quarantine treatments, especially for coldsensitive commodities such as citrus (Jacas et al., 2008).

Controlled atmosphere treatments are known to be effective against fruit flies and

\footnotetext{
Received for publication 16 June 2010. Accepted for publication 24 July 2010.

Adriana Contreras was funded by a scholarship from the Consejo Nacional de Ciencias y Tecnología (CONACyT) from México. Dr. Cristina Rojas-Argudo is supported partially by the European Social Fund.

${ }^{1}$ To whom reprint requests should be addressed; e-mail perez_mbe@gva.es.
}

other pests (Follett and Neven, 2006; Mitcham et al., 2003). Different works have investigated the use of insecticidal atmospheres (IA) consisting on high $\mathrm{CO}_{2}$ shocks previous or after cold exposure of citrus fruit to reduce the duration of the standard cold disinfestation quarantine treatment against $C$. capitata and thus alleviate chilling injury (CI) problems (Alonso et al., 2005a, 2005b; Palou et al., 2008a). In general, the effects of insecticidal treatments on treated produce considerably differ depending on species and cultivar (Follett and Neven, 2006). Therefore, the optimum combination of atmosphere gas composition, temperature, and length of application should be pursued for each pest-host system. For example, IA treatments consisting of exposure to $95 \% \mathrm{CO}_{2}$ at $20{ }^{\circ} \mathrm{C}$ for $20 \mathrm{~h}$ (Alonso et al., 2005a), $98 \% \mathrm{CO}_{2}$ at $22{ }^{\circ} \mathrm{C}$ for up to $24 \mathrm{~h}$ (Alonso et al., 2005a), and $95 \% \mathrm{CO}_{2}$ at $25^{\circ} \mathrm{C}$ for $20 \mathrm{~h}$ (Palou et al., 2008a) achieved complete insect mortality on 'Fortune' mandarins, 'Valencia' oranges, and 'Clemenules' mandarins, respectively, without affecting negatively fruit external appearance or sensory properties.

Today, IA at a curing temperature of $33{ }^{\circ} \mathrm{C}$ on citrus has also been studied to control postharvest green mold of mandarins (Palou et al., 2008b). These new physical methods combining heat and gas shocks could be interesting to control established pathogenic infections and/or induce fruit resistance to postharvest diseases. However, little information is available for the effects of high $\mathrm{CO}_{2}$ citrus exposure at high temperature followed by cold quarantine storage on overall fruit quality.

Conventionally, postharvest quality assessment has been conducted to evaluate the physicochemical quality of the fruit through parameters such as weight loss, firmness, maturity index, and acidity, among others. Additionally, the sensory evaluation of fruit is also performed to determine changes during postharvest handling. At present, the nutritional quality is gaining interest, being a component of the overall quality that is very much valued by consumers. In particular, citrus fruits are an important nutritional source of vitamin $\mathrm{C}$ and polyphenolic compounds with antioxidant properties such as flavonoids (Sánchez-Moreno et al., 2003). The necessity of preserving the health properties of citrus recommends that postharvest technologies would maintain both functional and nutritional quality until these reach the consumer. Lee and Kader (2000) reviewed the factors affecting postharvest content of vitamin $\mathrm{C}$ and concluded that temperature is the most important factor. In general, losses are accelerated by using high temperatures and long storage. However, low-temperature storage can also accelerate the loss of vitamin $\mathrm{C}$ in cold-sensitive fruit, even before $\mathrm{CI}$ is evident (Miller and Heilman, 1952). Therefore, the exposure of citrus fruit to high $\mathrm{CO}_{2}$ concentrations at different temperatures and the combination with different periods of cold storage might affect the physiology of the fruit, altering the biochemical components of citrus. Therefore, the aim of this work was to study the effect of IA $\left(95 \% \mathrm{CO}_{2}\right)$ applied at 23,28 , and $33{ }^{\circ} \mathrm{C}$ combined with short cold quarantine storage on physicochemical, sensory, and nutritional quality of 'Valencia' oranges.

\section{Materials and Methods}

\section{Fruit}

'Valencia' oranges (Citrus sinensis) were hand-harvested with an average maturity index of 10.1 from a local grove in Valencia, Spain, and transferred to the IVIA postharvest facilities where they were selected, randomized, washed with tap water, and dipped in a mixed solution of imazalil (1000 ppm) for 1 min. Subsequently, fruit were put into 12 homogeneous groups of 80 fruit each, which were placed in separate unlidded commercial cardboard boxes $(40 \times 29 \times 27 \mathrm{~cm})$.

\section{Inseciticidal atmosphere treatments}

For each period of time, four groups of 80 fruit were exposed for $20 \mathrm{~h}$ to the following IA treatments: 1) air atmosphere at $23 \pm 1{ }^{\circ} \mathrm{C}$ (control); 2) IA containing $95 \% \mathrm{CO}_{2}$ at $23 \pm$ $1{ }^{\circ} \mathrm{C}$; 3 ) IA containing $95 \% \mathrm{CO}_{2}$ at $28 \pm 1{ }^{\circ} \mathrm{C}$; and 4) IA containing $95 \% \mathrm{CO}_{2}$ at $33 \pm 1{ }^{\circ} \mathrm{C}$. In all cases, relative humidity (RH) was 
$85 \% \pm 5 \%$. IA exposure chambers consisted of hermetic Perspex cabinets $(82 \times 62 \times 87$ $\mathrm{cm}$ ) fitted with inlet and outlet ports through which $\mathrm{CO}_{2}$ (Alphagaz, N38; Air Liquid S.A., Madrid, Spain) passed at a rate adjusted to yield a concentration of $95 \%(\mathrm{v} / \mathrm{v})$ inside the cabinet and balance air. Gas was allowed to escape from the outlet port through a bubble tube to maintain the proper gas mixture in the chamber. Levels of $\mathrm{CO}_{2}, \mathrm{O}_{2}$, temperature, and $\mathrm{RH}$ were continuously monitored by means of the Control-Tec ${ }^{\circledR}$ system (Tecnidex S.A., Paterna, Valencia, Spain). Cabinets were installed inside a $40-\mathrm{m}^{3}$ storage room that was also set to each experimental temperature $\left(23,28\right.$, or $\left.33^{\circ} \mathrm{C}\right)$. Once IA treatments were accomplished, fruit were coated with a $10 \%$ total solids water wax containing polyethylene, shellac, and $0.5 \%$ of the fungicide thiabendazole (Brillaqua ${ }^{\circledR}$; Brillocera S.A., Beniparrell, Valencia, Spain).

After waxing, the fruits were exposed to the standard cold quarantine temperature of $1 \pm 0.5^{\circ} \mathrm{C}$ for 8,16 , or $24 \mathrm{~d}$ followed by $7 \mathrm{~d}$ of shelf life at $20{ }^{\circ} \mathrm{C}$ to simulate prompt fruit commercialization. Approximately 50 additional oranges were used to determine fruit quality at harvest (initial quality). Quality attributes were determined as follows.

\section{Materials}

Reagents 2,2-diphenyl-1-picrylhydrazyl $\left(\mathrm{DPPH}^{*}\right)$, potassium dihydrogen phosphate $\left(\mathrm{KH}_{2} \mathrm{PO}_{4}\right)$, meta-phosphoric acid (MPA), phosphoric acid $\left(\mathrm{H}_{3} \mathrm{PO}_{4}\right)$, Folin-Ciocalteu phenol reagents, sodium carbonate $\left(\mathrm{Na}_{2} \mathrm{CO}_{3}\right)$, gallic acid, and standard L-ascorbic acid (AA) were purchased from Sigma (Sigma-Aldrich Chemie, Steinhein, Germany). Acetic acid glacial and dimethyl sulfoxide (DMSO) were from Scharlau (Sentmenat, Spain). 1,4-dithioDL-threitol (DTT) and hesperidin [hesperitin7-0-rutinoside (HES)] were obtained from Fluka (Sigma Co., Barcelona, Spain). Narirutin [naringenin-7-rutinoside (NAT)] and didymin [isosakuranetin-7-rutinoside (DID)] were purchased from Extrasynthese (Genay, France). All solvents were of high-performance liquid chromatography grade and ultrapure water (Milli-Q; Millipore Corporation, Billerica, MA) was used.

\section{Physicochemical quality}

Weight loss. Lots of 30 fruits per treatment were used to measure weight loss. The same fruit was weighed at the beginning of the experiment and at the end of each storage period. The results were expressed as the percentage of initial weight loss.

Firmness. Firmness of 20 oranges per treatment was determined at the end of each storage time using an Instron Universal Testing Machine (Model 3343; Instron Corp., Canton, MA). Each fruit was compressed between two flat surfaces closing together at a rate of $5 \mathrm{~mm} \cdot \mathrm{min}^{-1}$. The instrument gave the deformation after application of a load of $10 \mathrm{~N}$ to the equatorial region of the fruit. Results were expressed as percentage of deformation related to initial diameter.

Ethanol and acetaldehyde contents. Ethanol and acetaldehyde contents (EC and AC, respectively) in juice were determined by head-space gas chromatography. Ten fruits each in three replicates per treatment were analyzed. Five milliliters of orange juice was transferred to $10-\mathrm{mL}$ vials with crimp-top caps and TFE/silicone septum seals and frozen until analysis. EC and AC were analyzed in a gas chromatograph (Thermo Fisher Scientific, Inc., Waltham, MA) equipped with an autosampler, a flame ionization detector, and fitted with a Poropak QS 80/100 column (Waters Corporation, Millord, MA) (1.2 $\mathrm{m} \times$ $0.32 \mathrm{~cm})$. Temperatures of the oven, injector, and detector were 150,175 , and $200{ }^{\circ} \mathrm{C}$, respectively. Helium was used as the carrier gas at a flow rate of $28 \mathrm{~mL} \cdot \mathrm{min}^{-1}$. Onemilliliter sample of the head-space was withdrawn from each vial previously equilibrated in the autosampler incubation chamber for 10 $\min$ at $40{ }^{\circ} \mathrm{C}$. EC and $\mathrm{AC}$ concentrations were calculated using peak areas of the samples relative to the peak areas of standard solutions. Results were expressed as $\mathrm{mg} / 100 \mathrm{~mL}$ juice.

External disorders. Eighty fruit per treatment were inspected for external physiological disorders at the end of each storage period. The different degrees of disorders were rated as $0=$ none, $1=$ light, $2=$ moderate, and $3=$ severe. Light was considered when less than $10 \%$ of the fruit surface was affected and severe when more than $20 \%$ of the fruit surface was affected. Results were converted to an average index.

Internal quality parameters. Soluble solids concentration (SSC) was measured with a digital refractometer (Atago, Model PR1; Atago Co., LTD., Tokyo, Japan) and titratable acidity (TA) was determined by titration with $0.1 \mathrm{~N} \mathrm{NaOH}$ and phenolphthalein indicator and expressed as grams of citric acid per $100 \mathrm{~mL}$ of orange juice. The maturity index (MI) was calculated as SSC/TA ratio. The juice from three replicates of 10 fruit each was used to determine these parameters.

Sensory analysis. Sensory evaluation was conducted by 10 trained judges. Panelists rated flavor on a 9-point scale, in which 1 to 3 represented a range of non-acceptable quality with the presence of off-flavor, 4 to 6 represented a range of acceptable quality, and 7 to 9 represented a range of excellent quality. Off-flavor presence was evaluated using a 6-point scale in which $0=$ absence of offflavor and $5=$ high presence of off-flavor.

One sample consisted of whole segments taken from approximately eight individual fruits. Samples were presented to panelist in trays labeled with three-digit random codes and served at room temperature $\left(25 \pm 1{ }^{\circ} \mathrm{C}\right)$. The judges had to taste several segments of each treatment to compensate, as far as possible, for biological variation of material. Mineral spring water was provided for rinsing between samples.

\section{Nutritional quality}

$D P P H^{\circ}$ radical-scavenging capacity. The total antioxidant capacity (TAC) was evaluated by the $\mathrm{DPPH}^{\cdot}$ assay. A total of $0.4 \mathrm{~mL}$ of orange juice diluted with $0.8 \mathrm{~mL}$ methanol was centrifuged at $12,000 \mathrm{rpm}$ and $4{ }^{\circ} \mathrm{C}$ for
20 min. Six methanolic dilutions from the supernatant $(0.075 \mathrm{~mL})$ were mixed with $0.2925 \mathrm{~mL}$ of $\mathrm{DPPH}^{\cdot}\left(24 \mathrm{mg} \cdot \mathrm{L}^{-1}\right)$ and kept in darkness for $40 \mathrm{~min}$. Afterward, the change in absorbance at $515 \mathrm{~nm}$ was measured in a Multiskan spectrum microplate reader (Thermo Labsystem; Thermo Fisher Scientific Inc., Waltham, MA).

For each dilution, the percentage of remaining $\mathrm{DPPH}^{*}$ was determined on the basis of the $\mathrm{DPPH}^{\circ}$ standard curve. The amount of juice in each dilution was plotted against the amount of $\mathrm{DPPH}^{*}$ radical remaining. Using the curve obtained, the $\mathrm{EC}_{50}$ value was calculated. This result expressed the amount of orange juice (L) needed to reduce $1 \mathrm{~kg}$ of $\mathrm{DPPH}^{*}$ by $50 \%$; thus, lower values mean higher antioxidant activity.

Total ascorbic acid. Total AA was determined by the sum of AA plus L-dehydroascorbic acid by using the reducing agent DTT (Sánchez-Mata et al., 2000). One milliliter of orange juice was diluted to $10 \mathrm{~mL}$ with $2.5 \%$ $(w / v)$ MPA. Two milliliters of this solution was mixed with $0.4 \mathrm{~mL}$ of DTT $\left(20 \mathrm{mg} \cdot \mathrm{mL}^{-1}\right)$ for $2 \mathrm{~h}$ in darkness. Afterward, the extracts were filtered through a $0.45-\mu \mathrm{m}$ Millipore filter before being analyzed by high-performance liquid chromatography (HPLC).

The HPLC analyses were performed on a Lachrom Elite HPLC (Merck Hitachi, Darmstadt, Germany) equipped with an L2200 autosampler, L-2130 quaternary pump, L-2300 column oven, and L-2450 diode array detector. System conditions were: injection volume $20 \mu \mathrm{L}$, oven $25{ }^{\circ} \mathrm{C}$, detector wavelength $243 \mathrm{~nm}$, flow rate $1 \mathrm{~mL} \cdot \mathrm{min}^{-1}$, column Lichospher $100 \mathrm{RP}-18$ of $25 \times 0.4 \mathrm{~cm}$ preceded by a precolumn $(4 \times 4 \mathrm{~mm})$ with a 5 - $\mu \mathrm{m}$ particle size (Merck, Darmstadt, Germany). The mobile phase was $2 \% \mathrm{KH}_{2} \mathrm{PO}_{4}$ adjusted to $\mathrm{pH} 2.3$ with $\mathrm{H}_{3} \mathrm{PO}_{4}$. Results were expressed as mg AA/100 mL of juice.

Flavanone glycosides. HES, NAT, and DID $(\mathrm{mg} / 100 \mathrm{~mL})$ were determined by the method described by Cano et al. (2008) slightly modified. Two milliliters of orange juice was homogenized with $2 \mathrm{~mL}$ DMSO methanol $(1: 1 \mathrm{v} / \mathrm{v})$ and centrifuged for $30 \mathrm{~min}$ at $12,000 \mathrm{rpm}$ and $4{ }^{\circ} \mathrm{C}$. The supernatant was filtered through one $0.45-\mu \mathrm{m}$ nylon filter and analyzed by HPLC-DAD using the HPLC equipment described previously. System conditions were: injection volume $10 \mu \mathrm{L}$, oven $25^{\circ} \mathrm{C}$, detector wavelength $280 \mathrm{~nm}$, flow rate $1 \mathrm{~mL} \cdot \mathrm{min}^{-1}$, column Lichospher $100 \mathrm{RP}-18$ of $25 \times 0.4 \mathrm{~cm}$ preceded by a precolumn $(4 \times 4$ $\mathrm{mm})$ of a $5-\mu \mathrm{m}$ particle size (Merck). The mobile phase was acetonitrile (A): $0.6 \%$ acetic acid (B) with initial condition of $10 \%$ A for 2 min, reaching $75 \% \mathrm{~A}$ in the next $28 \mathrm{~min}$, then back to the initial condition in $1 \mathrm{~min}$, and held for $5 \mathrm{~min}$ before the next sample injection. The main flavanone glycosides (FGs) were identified by matching their respective spectra and retention times with those of commercially obtained standards. NAT, HES, and DID contents were calculated by comparing the integrated peak areas of each individual compounds with that of its pure standards. Results were expressed as $\mathrm{mg} / 100 \mathrm{~mL}$. 
Total phenolic content. The orange juices were analyzed for total phenolics by the FolinCiocalteu colorimetric method. A total of 0.3 $\mathrm{mL}$ of orange juice was diluted with $1.7 \mathrm{~mL}$ of $80 \%$ aqueous methanol. Appropriately diluted extract $(0.4 \mathrm{~mL})$ was mixed with $2 \mathrm{~mL}$ of Folin Ciocalteau commercial reagent (previously diluted with water $1: 10, v / v$ ) and incubated for $1 \mathrm{~min}$ before $1.6 \mathrm{~mL}$ sodium carbonate $(7.5 \% \mathrm{w} / \mathrm{v})$ was added. The mixture was incubated for $1 \mathrm{~h}$ at room temperature. The absorbance of the resulting blue solution was measured spectrophotometrically at 765 nm (Thermo UV1; Thermo Electron Corporation, Auchtermuchty Fife, U.K.) and the concentration of total phenolics was expressed as gallic acid equivalents per $100 \mathrm{~mL}$ (mg $\mathrm{GAE} / 100 \mathrm{~mL}$ ). All extracts were analyzed in triplicate.

Statistical analysis. Statistical analysis was performed using STATGRAPHICS Plus 4.1 (Manugistics, Inc., Rockville, MD). Significance between means was determined by least significant difference at $P \leq 0.05$.

\section{Results and Discussion}

Physicochemical quality. The use of high temperatures is known to enhance the insecticidal activity of quarantine treatments (Vincent et al., 2003), but also it might increase fruit weight loss in the same way that conventional curing of citrus increases fruit weight loss (Plaza et al., 2003; Porat et al., 2000). Figure 1 shows the weight loss of 'Valencia' oranges exposed to the IA treatments $\left(95 \% \mathrm{CO}_{2}\right)$ at 23,28 , or $33^{\circ} \mathrm{C}$ followed by cold quarantine storage at $1{ }^{\circ} \mathrm{C}$ for 8,16 , or $24 \mathrm{~d}$ and a shelf life period at $20{ }^{\circ} \mathrm{C}$ for $7 \mathrm{~d}$. The exposure of 'Valencia' oranges to the IA at different temperatures did not increase the weight loss compared with the control. Interestingly, oranges exposed to IA at $28{ }^{\circ} \mathrm{C}$ had the lowest weight loss. It is known that exposure to moderate temperatures and high $\mathrm{RH}$ induces wound healing by biosynthesis of lignin and other phenolic compounds (Mulas and Schirra, 2007; Nunes et al., 2007). Therefore, this mild heat treatment probably induced positive changes in the rind of the mandarins that helped reduce orange weight loss.

Fruit firmness significantly decreased after $24 \mathrm{~d}$ of storage at $1{ }^{\circ} \mathrm{C}$ (Table 1$)$. Although no relevant differences were observed between IA-treated fruit and control fruit, fruit exposed to the IA at 28 or $23{ }^{\circ} \mathrm{C}$ maintained higher firmness values than control fruit after 8 or $24 \mathrm{~d}$ of cold storage, respectively, which is in accordance with the lower weight loss of these treatments under those storage conditions (Fig. 1). In general, the treatments had no harmful effect on fruit firmness and the maximal percentage of deformation remained below the 5\% threshold established for firmness in citrus fruit (Martínez-Jávega et al., 1998). Similar results have been reported on mandarins and oranges exposed to combined cold and IA quarantine treatments (Alonso et al., 2005a, 2005b; Palou et al., 2008a).
Figure 2 shows the EC and AC of 'Valencia' oranges exposed to combined IA and cold quarantine treatments. The EC and $\mathrm{AC}$ of $\mathrm{CO}_{2}$-treated oranges remained fairly constant as cold quarantine storage time increased. 'Valencia' oranges exposed to high $\mathrm{CO}_{2}$ had more EC and $\mathrm{AC}$ than those exposed to air. $\mathrm{EC}$ and $\mathrm{AC}$ were lower in fruit exposed to the IA at $23{ }^{\circ} \mathrm{C}$ than in those exposed at 28 and $33{ }^{\circ} \mathrm{C}$. Under these high-temperature

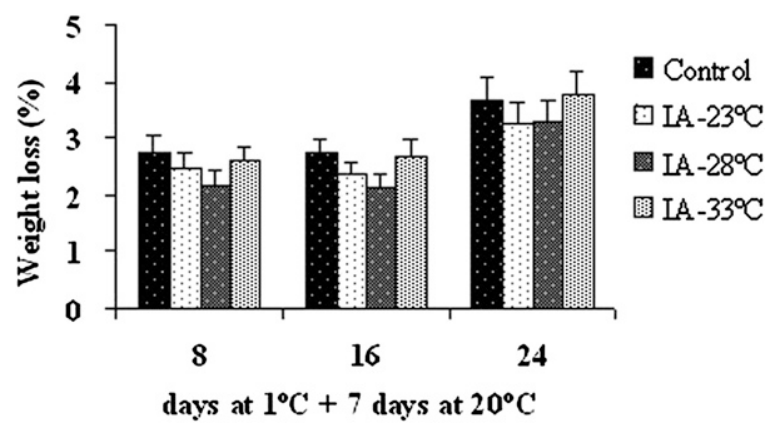

Fig. 1. Weight loss of 'Valencia' oranges exposed to air (control) or an insecticidal atmosphere (IA, 95\% $\mathrm{CO}_{2}$ ) at 23,28 , or $33^{\circ} \mathrm{C}$ for $20 \mathrm{~h}$ followed by a cold quarantine storage at $1{ }^{\circ} \mathrm{C}$ for 8,16 , or $24 \mathrm{~d}$ and a shelf life of $7 \mathrm{~d}$ at $20^{\circ} \mathrm{C}$. Bars indicate sD at $P \leq 0.05$.

Table 1. Firmness of 'Valencia' oranges exposed to air (control) or an insecticidal atmospheres (IA, 95\% $\mathrm{CO}_{2}$ ) at 23,28 , or $33^{\circ} \mathrm{C}$ for $20 \mathrm{~h}$ followed by a cold quarantine storage at $1{ }^{\circ} \mathrm{C}$ for 8,16 , or $24 \mathrm{~d}$ and a shelf life of $7 \mathrm{~d}$ at $20^{\circ} \mathrm{C}$.

\begin{tabular}{lcc}
\hline Cold quarantine period (days) & IA treatment & Firmness (\% deformation) \\
\hline Initial (at harvest) & & $2.24 \pm 0.41$ \\
8 & Control (air at $\left.23{ }^{\circ} \mathrm{C}\right)$ & $2.28 \pm 0.36 \mathrm{~b}$ \\
& IA $23{ }^{\circ} \mathrm{C}$ & $2.24 \pm 0.30 \mathrm{ab}$ \\
& IA $28{ }^{\circ} \mathrm{C}$ & $2.08 \pm 0.20 \mathrm{a}$ \\
& IA $33{ }^{\circ} \mathrm{C}$ & $2.36 \pm 0.27 \mathrm{~b}$ \\
& & \\
16 & Control (air at $\left.23{ }^{\circ} \mathrm{C}\right)$ & $2.27 \pm 0.36 \mathrm{a}$ \\
& IA $23{ }^{\circ} \mathrm{C}$ & $2.05 \pm 0.41 \mathrm{a}$ \\
& IA $28{ }^{\circ} \mathrm{C}$ & $2.21 \pm 0.38 \mathrm{a}$ \\
& IA $33{ }^{\circ} \mathrm{C}$ & $2.20 \pm 0.36 \mathrm{a}$ \\
& & $3.13 \pm 0.38 \mathrm{~b}$ \\
& Control (air at $\left.23{ }^{\circ} \mathrm{C}\right)$ & $2.75 \pm 0.44 \mathrm{a}$ \\
& IA $23{ }^{\circ} \mathrm{C}$ & $2.93 \pm 0.49 \mathrm{ab}$ \\
\end{tabular}

Previous to firmness measurement, fruit was kept at $20^{\circ} \mathrm{C}$ for $7 \mathrm{~d}$ to simulate shelf life conditions. Values give means $\pm \operatorname{SD}(n=3)$. For each cold quarantine period, means with the same letter are not different at $P \leq$ 0.05 .

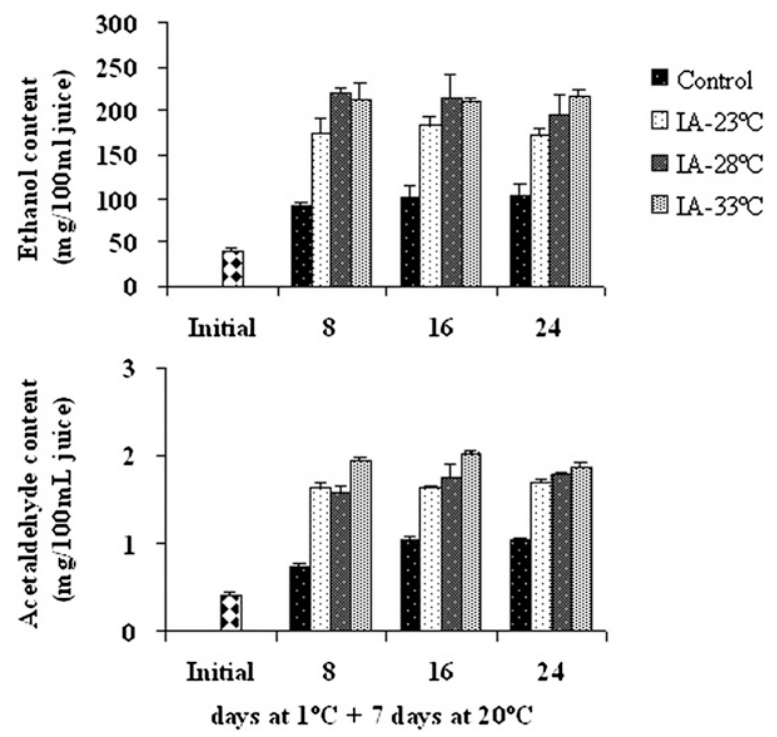

Fig. 2. Ethanol and acetaldehyde contents of 'Valencia' oranges exposed to air (control) or an insecticidal atmospheres (IA, $95 \% \mathrm{CO}_{2}$ ) at 23,28 , or $33{ }^{\circ} \mathrm{C}$ for $20 \mathrm{~h}$ followed by a cold quarantine storage at $1{ }^{\circ} \mathrm{C}$ for 8,16 , or $24 \mathrm{~d}$ and a shelf life of $7 \mathrm{~d}$ at $20^{\circ} \mathrm{C}$. Bars indicate $\mathrm{SD}(\mathrm{n}=3)$. 
conditions, EC exceeded the limit slightly, set up at $200 \mathrm{mg} / 100 \mathrm{~mL}$ juice, considered by some authors as the level of off-flavor build-up risk (Hagenmaier, 2002; Ke and Kader, 1990).

An increase in the concentration of these fermentative volatile compounds resulting from exposure to high $\mathrm{CO}_{2}$ and/or low $\mathrm{O}_{2}$ atmospheres has also been described in other citrus cultivars (Alonso et al., 2005a; Ke and Kader, 1990; Pesis and Avissar, 1989). Although the levels of volatile built up as a consequence of controlled atmosphere exposure depends on fruit cultivar, treatment conditions, and duration, these works report similar volatile built up to the results found in our work when IA treatments were applied at temperatures below $25^{\circ} \mathrm{C}$. In general, the level of ethanol, acetaldehyde, and other internal volatiles associated with anaerobic conditions increased as the temperature of the application of the IA treatment increased.

The exposure of 'Valencia' oranges to the IA did not cause any rind damage. These results are in agreement with Alonso et al. (2005b) and Palou et al. (2008a) in 'Fortune' and 'Clemenules' mandarins, respectively. However, Ke and Kader (1990) described that longer exposures to high $\mathrm{CO}_{2}$ atmospheres ( 9 to $14 \mathrm{~d}$ ) induced severe rind injuries in 'Valencia' oranges.

Application of IA treatments did not affect TA, SSC, or MI (data not shown). Similarly, Alonso et al. (2005a) and Palou et al. (2008a) showed no effect of high $\mathrm{CO}_{2}$ exposure for short storage periods on internal fruit quality parameters of 'Fortune' and 'Clemenules' mandarins, respectively. However, Pesis and Avissar (1989) showed that the exposure of oranges to high $\mathrm{CO}_{2}$ atmospheres for 20 to 40 $\mathrm{h}$ decreased TA and increased MI.

Sensory analysis. Overall flavor and offflavors were unaffected by the IA treatment or the length of the cold quarantine period. Judges evaluated the oranges as acceptable at the end of storage and having a very slight off-flavor (Table 2). Similarly, no negative influence on fruit sensory quality was found on 'Valencia' oranges or 'Fortune' mandarins exposed to IA for short periods (Alonso et al., 2005a, 2005b). However, the flavor of 'Clemenules' mandarins decreased after short-term exposure to high $\mathrm{CO}_{2}$ atmospheres (Palou et al., 2008a). These differences are because several factors such as electrical conductivity, acidity, SSC, and cultivar can influence the perception of off-flavors (Ke and Kader, 1990; Ke et al., 1991).

Nutritional quality. Table 3 shows the $\mathrm{DPPH} \bullet$ radical-scavenging capacity (RSC) of 'Valencia' oranges treated with IA at high temperature combined with short cold quarantine periods. The DPPH・ RSC of the oranges was unaffected by the exposure to $95 \% \mathrm{CO}_{2}$ or when the cold quarantine period increased, except IA $33{ }^{\circ} \mathrm{C}$-treated oranges. In this treatment, $\mathrm{EC}_{50}$ values increased (i.e., DPPH $\bullet$ RSC decreased) at the end of the cold quarantine storage $(P \leq 0.05)$. A high correlation between phenolic compounds and TAC in different fruits and vegetables has been widely reported (Kevers et al., 2007). In citrus fruit, AA in addition to phenolic content might contribute from $33 \%$ to $95 \%$ of the TAC (Gil-Izquierdo et al., 2002; Palma et al., 2005; SánchezMoreno et al., 2003). In our work, neither TAA nor total phenolics decreased in IA $33{ }^{\circ} \mathrm{C}$-treated oranges; therefore, other phytochemicals such as carotenoids would be involved in the observed DPPH• RSC decrease.

TAA content of 'Valencia' oranges ranged from 34 to $42 \mathrm{mg} / 100 \mathrm{~mL}$ (Table 3 ). The TAA content of 'Valencia' oranges was unaffected by $95 \% \mathrm{CO}_{2}$ exposure in fruits stored at cold quarantine temperature for 8 or $16 \mathrm{~d}$. However, after $24 \mathrm{~d}$ cold quarantine storage, TAA increased in control fruit but no increase was observed in the rest of the treatments. In accordance with our results, Rapisarda et al. (2008) reported an increase in the TAA content of 'Valencia' oranges during storage at $6{ }^{\circ} \mathrm{C}$. Therefore, exposure to $95 \% \mathrm{CO}_{2}$ could

Table 2. Sensory analysis of 'Valencia' oranges exposed to air (control) or an insecticidal atmospheres (IA, $95 \% \mathrm{CO}_{2}$ ) at 23,28 , or $33^{\circ} \mathrm{C}$ for $20 \mathrm{~h}$ followed by a cold quarantine storage at $1{ }^{\circ} \mathrm{C}$ for 8,16 , or $24 \mathrm{~d}$ and a shelf life of $7 \mathrm{~d}$ at $20^{\circ} \mathrm{C}$.

\begin{tabular}{|c|c|c|c|}
\hline Cold quarantine period (days) & IA treatment & Off-flavor (0-5) & Flavor (1-9) \\
\hline Initial (at harvest) & & $0.00 \pm 0.00$ & $7.12 \pm 0.71$ \\
\hline \multirow[t]{4}{*}{8} & Control (air at $23^{\circ} \mathrm{C}$ ) & $0.67 \pm 1.30 \mathrm{a}$ & $6.33 \pm 1.44 \mathrm{a}$ \\
\hline & IA $23{ }^{\circ} \mathrm{C}$ & $1.25 \pm 1.42 \mathrm{a}$ & $5.58 \pm 1.56 a$ \\
\hline & IA $28^{\circ} \mathrm{C}$ & $1.08 \pm 1.24 \mathrm{a}$ & $5.33 \pm 1.61 \mathrm{a}$ \\
\hline & IA $33{ }^{\circ} \mathrm{C}$ & $1.08 \pm 1.44 \mathrm{a}$ & $5.00 \pm 1.86 \mathrm{a}$ \\
\hline \multirow[t]{4}{*}{16} & Control (air at $23{ }^{\circ} \mathrm{C}$ ) & $0.82 \pm 0.98 \mathrm{a}$ & $5.36 \pm 1.80 \mathrm{a}$ \\
\hline & IA $23{ }^{\circ} \mathrm{C}$ & $1.00 \pm 1.26 \mathrm{a}$ & $5.09 \pm 1.64 \mathrm{a}$ \\
\hline & IA $28^{\circ} \mathrm{C}$ & $1.36 \pm 1.50 \mathrm{a}$ & $4.91 \pm 1.76 a$ \\
\hline & IA $33{ }^{\circ} \mathrm{C}$ & $1.55 \pm 1.21 \mathrm{a}$ & $5.00 \pm 2.05$ \\
\hline \multirow[t]{4}{*}{24} & Control (air at $23{ }^{\circ} \mathrm{C}$ ) & $0.46 \pm 0.78 \mathrm{a}$ & $6.62 \pm 1.19 a$ \\
\hline & IA $23{ }^{\circ} \mathrm{C}$ & $1.38 \pm 1.45 \mathrm{a}$ & $5.54 \pm 1.51 \mathrm{a}$ \\
\hline & IA $28^{\circ} \mathrm{C}$ & $1.23 \pm 1.36 \mathrm{a}$ & $5.46 \pm 1.66 a$ \\
\hline & IA $33{ }^{\circ} \mathrm{C}$ & $0.92 \pm 1.26 \mathrm{a}$ & $5.92 \pm 1.61 \mathrm{a}$ \\
\hline
\end{tabular}

Previous to sensory evaluation, fruit was kept at $20{ }^{\circ} \mathrm{C}$ for $7 \mathrm{~d}$ to simulate shelf life conditions. Values give means \pm SD. For each cold quarantine period, means with the same letter are not different at $P \leq 0.05$.

Table 3. DPPH• radical-scavenging capacity (DPPH• RSC) and bioactive compounds of 'Valencia' oranges exposed to air (control) or an insecticidal atmospheres (IA, $95 \% \mathrm{CO}_{2}$ ) at 23,28 , or $33{ }^{\circ} \mathrm{C}$ for $20 \mathrm{~h}$ followed by a cold quarantine storage at $1{ }^{\circ} \mathrm{C}$ for 8,16 , or $24 \mathrm{~d}$ and a shelf life of $7 \mathrm{~d}$ at $20{ }^{\circ} \mathrm{C}$.

\begin{tabular}{|c|c|c|c|c|c|c|c|}
\hline $\begin{array}{l}\text { Cold quarantine } \\
\text { period (days) }\end{array}$ & IA treatment & $\begin{array}{c}\mathrm{DPPH} \bullet \mathrm{RSC} \\
\left(\mathrm{EC}_{50}\right) \\
(\mathrm{L} \text { juice } / \mathrm{Kg} \mathrm{DPPH})\end{array}$ & $\begin{array}{l}\text { TAA } \\
\text { (mg/100 } \mathrm{mL} \\
\text { juice) }\end{array}$ & $\begin{array}{c}\text { TPC } \\
\text { (mg GAE } / 100 \mathrm{~mL} \\
\text { juice) }\end{array}$ & \multicolumn{3}{|c|}{ FGs (mg/100 mL juice) } \\
\hline Initial (at harvest) & & $233.0 \pm 14.2$ & $34.71 \pm 1.40$ & $93.20 \pm 4.82$ & $2.86 \pm 0.24$ & $21.75 \pm 1.21$ & $0.97 \pm 0.08$ \\
\hline \multirow[t]{4}{*}{8} & Control (air at $23^{\circ} \mathrm{C}$ ) & $224.3 \pm 10.8$ a A & $39.15 \pm 1.47$ a A & $91.23 \pm 4.47 \mathrm{a} \mathrm{A}$ & $3.26 \pm 0.13$ a A & $27.83 \pm 0.31$ a A & $1.02 \pm 0.08 \mathrm{a} \mathrm{A}$ \\
\hline & IA $23{ }^{\circ} \mathrm{C}$ & $229.5 \pm 7.1 \mathrm{a} \mathrm{A}$ & $37.57 \pm 1.23 \mathrm{a} \mathrm{AB}$ & $90.21 \pm 2.02$ a A & $2.85 \pm 0.05$ a A & $27.47 \pm 0.86 \mathrm{a} \mathrm{A}$ & $0.96 \pm 0.00 \mathrm{a} \mathrm{A}$ \\
\hline & IA $28{ }^{\circ} \mathrm{C}$ & $238.6 \pm 19.5$ a A & $39.30 \pm 1.18 \mathrm{a} \mathrm{A}$ & $93.54 \pm 1.64 \mathrm{a} \mathrm{A}$ & $3.02 \pm 0.53$ a A & $26.36 \pm 1.36 \mathrm{a} \mathrm{A}$ & $0.90 \pm 0.11 \mathrm{a} \mathrm{A}$ \\
\hline & IA $33{ }^{\circ} \mathrm{C}$ & $206.3 \pm 3.6$ a A & $36.21 \pm 1.17$ a A & $98.70 \pm 3.85 \mathrm{a} \mathrm{A}$ & $2.95 \pm 0.28 \mathrm{a} \mathrm{A}$ & $26.88 \pm 1.61$ a A & $0.87 \pm 0.05 \mathrm{aA}$ \\
\hline \multirow{3}{*}{16} & IA $23{ }^{\circ} \mathrm{C}$ & $228.7 \pm 14.8$ a A & $35.50 \pm 1.53$ a A & $99.74 \pm 7.21$ a A & $2.84 \pm 0.21 \mathrm{a} \mathrm{A}$ & $25.08 \pm 1.23 \mathrm{a} \mathrm{A}$ & $0.84 \pm 0.07$ a A \\
\hline & IA $28{ }^{\circ} \mathrm{C}$ & $219.5 \pm 35.6$ a A & $35.85 \pm 1.29 \mathrm{a} \mathrm{A}$ & $99.10 \pm 5.28$ a A & $2.86 \pm 0.22$ a A & $25.27 \pm 0.28 \mathrm{a} \mathrm{A}$ & $0.79 \pm 0.07$ a A \\
\hline & IA $33{ }^{\circ} \mathrm{C}$ & $194.9 \pm 11.7$ a A & $36.21 \pm 2.60 \mathrm{a} \mathrm{A}$ & $107.19 \pm 11.20 \mathrm{a} \mathrm{A}$ & $2.97 \pm 0.23 \mathrm{a} \mathrm{A}$ & $27.51 \pm 1.01 \mathrm{~b} \mathrm{~A}$ & $0.80 \pm 0.03 \mathrm{a} \mathrm{A}$ \\
\hline \multirow[t]{3}{*}{24} & Control (air at $23^{\circ} \mathrm{C}$ ) & $216.1 \pm 2.1 \mathrm{a} \mathrm{A}$ & $42.31 \pm 1.65 \mathrm{~b} \mathrm{~B}$ & $105.86 \pm 4.99$ a B & $2.88 \pm 0.18$ a A & $27.67 \pm 0.61 \mathrm{a} \mathrm{A}$ & $0.85 \pm 0.07 \mathrm{a} \mathrm{A}$ \\
\hline & IA $23{ }^{\circ} \mathrm{C}$ & $227.0 \pm 5.7 \mathrm{a} \mathrm{A}$ & $38.84 \pm 0.49$ a B & $100.66 \pm 4.19 \mathrm{a} \mathrm{A}$ & $2.94 \pm 0.11 \mathrm{a} \mathrm{A}$ & $26.66 \pm 1.27 \mathrm{a} \mathrm{A}$ & $0.88 \pm 0.01 \mathrm{a} \mathrm{A}$ \\
\hline & IA $28{ }^{\circ} \mathrm{C}$ & $241.6 \pm 17.2$ a A & $36.94 \pm 2.22 \mathrm{a} \mathrm{A}$ & $103.55 \pm 9.38$ a A & $3.20 \pm 0.11 \mathrm{a} \mathrm{A}$ & $25.88 \pm 0.64$ a A & $0.94 \pm 0.06 \mathrm{a} A$ \\
\hline
\end{tabular}

Previous to DPPH• RSC and bioactive compounds determination, fruit was kept at $20^{\circ} \mathrm{C}$ for $7 \mathrm{~d}$ to simulate shelf life conditions. Values give means $\pm \mathrm{sD}(\mathrm{n}=3)$. For each cold quarantine period, different treatments with the same lower case letter are not different at $P \leq 0.05$. For each treatment and different quarantine periods, means with the same capital letter are not different at $P \leq 0.05$.

$\mathrm{DPPH} \bullet \mathrm{RSC}=\mathrm{DPPH} \bullet$ radical-scavenging capacity $; \mathrm{TAA}=$ total ascorbic acid $; \mathrm{TPC}=$ total phenolic content $\mathrm{FGs}=$ flavanone glycosides; $\mathrm{NAT}=$ narirutin $; \mathrm{HES}=$ hesperidin; DID = didymin 
diminish the capacity for the AA synthesis during fruit storage.

The FG contents of 'Valencia' oranges exposed to IA and cold quarantine were in the range of those reported for citrus fruit (Table 3) (Dhuique-Mayer et al., 2005; Nogata et al., 2006). The HES, NAT, and DID contents of 'Valencia' oranges were unaffected by the increase in the cold quarantine period $(P \leq$ 0.05). Palma et al. (2005) did not find significant differences in HES, NAT, or DID in 'Fortune' mandarin during 3 months of storage at $5{ }^{\circ} \mathrm{C}$. In general, the $\mathrm{FG}$ contents were unaffected by the exposure to $95 \% \mathrm{CO}_{2}$, except on oranges exposed to the IA at $33{ }^{\circ} \mathrm{C}$ after $16 \mathrm{~d}$ of cold quarantine storage that had more HES than the rest of the samples.

Total phenolic content (TPC) of 'Valencia' oranges ranged from $90.21 \pm 2.02$ to $107.80 \pm$ $2.46 \mathrm{mg} / 100 \mathrm{~mL}$ (GAE) (Table 3). GilIzquierdo et al. (2002) found that TPC of orange juice and pulp after domestic and commercial squeezing was 87.8 and $71.7 \mathrm{mg} /$ $100 \mathrm{~mL}$, respectively. Gardner et al. (2000) also found that total polyphenols ranged from $50.4 \pm 1.0$ to $75.5 \pm 1.8 \mathrm{mg} / 100 \mathrm{~mL}$ (GAE) in three commercial orange juices.

In general, there was an increase in the TPC of 'Valencia' oranges when the cold quarantine period increased. This result is in accordance with Patil et al. (2004), which reported higher flavanoid content after cold storage of citrus fruit. This was associated with an increase in the phenylalanine ammonia lyase (PAL) activity during low-temperature storage. On the other hand, other works have shown that cold storage either did not influence or decreased the citrus TPC. For example, Palma et al. (2005) did not find differences in the TPC of 'Fortune' mandarins after $90 \mathrm{~d}$ of storage at $5{ }^{\circ} \mathrm{C}$, whereas Rapisarda et al. (2008) found a decrease of total phenolics in 'Valencia' oranges after $40 \mathrm{~d}$ of storage at $6{ }^{\circ} \mathrm{C}$, which was attributed to senescence during storage.

It can be concluded from these results that the exposure of 'Valencia' oranges to $95 \%$ $\mathrm{CO}_{2}$ at 23,28 , or $33{ }^{\circ} \mathrm{C}$ combined with short cold quarantine periods did not induce any harmful effect on physicochemical, sensory, or nutritional citrus quality. Exposure of 'Valencia' oranges to $95 \%$ of $\mathrm{CO}_{2}$ at $28{ }^{\circ} \mathrm{C}$ for $20 \mathrm{~h}$ was beneficial to maintain the fruit quality, reducing weight and firmness loss. Combination of the IA and cold quarantine periods of 8 or $16 \mathrm{~d}$ did not affect the TAA content of the fruits; whereas when the cold quarantine period increased to $24 \mathrm{~d}$, fruit exposed to high $\mathrm{CO}_{2}$ atmospheres had lower TAA content than control fruit. Therefore, this high $\mathrm{CO}_{2}$ atmosphere, alone or combined with curing temperatures, could be applied as insecticidal treatment or for the control of citrus moulds without negatively affecting the quality of 'Valencia' orange.

\section{Literature Cited}

Alonso, M., J. Jacas, and M.A. del Río. 2005a. Carbon dioxide diminishes cold tolerance of third instar larvae of Ceratitis capitata Wiedemann (Diptera: Tephritidae) in 'Fortune' mandarins: Implications for citrus quarantine treatments. Postharvest Biol. Technol. 36:103-111.

Alonso, M., L. Palou, J. Jacas, and M.A. del Río. 2005b. Effect of short-term exposure to $\mathrm{CO}_{2}-$ enriched atmospheres on 'Valencia' orange quality. Acta Hort. 682:1077-1082.

Cano, A., A. Medina, and A. Bermejo. 2008. Bioactive compounds in different citrus varieties. Discrimination among cultivars. J. Food Compost. Anal. 21:377-381.

Dhuique-Mayer, C., C. Caris-Veyrat, P. Ollitrault, F. Curk, and M.J. Amiot. 2005. Varietal and interspecific influence on micronutrient contents in citrus from the Mediterranean area. J. Agr. Food Chem. 53:2140-2145.

Follett, P.A. and L.G. Neven. 2006. Current trends in quarantine entomology. Annu. Rev. Entomol. 51:359-385.

Gardner, P.T., T.A.C. White, D.B. McPhail, and G.G. Duthie. 2000. The relative contributions of vitamin $\mathrm{C}$, carotenoids and phenolics to the antioxidant potential of fruit juices. Food Chem. 68:471-474.

Gil-Izquierdo, A., M.I. Gil, and F. Ferreres. 2002. Effect of processing techniques at industrial scale on orange juice antioxidant and beneficial health compounds. J. Agr. Food Chem. 50: 5107-5114.

Hagenmaier, R.D. 2002. The flavor of mandarin hybrids with different coatings. Postharvest Biol. Technol. 24:79-87.

Jacas, J.A., L. Palou, F. Beitia, and M.A. del Río. 2008. Controlled in vivo infestation of mandarin fruit with Ceratitis capitata for development of quarantine treatments. Span. J. Agric. Res. 6:434-440.

Ke, D. and A.A. Kader. 1990. Tolerance of 'Valencia' oranges to controlled atmospheres as determined by physiological responses and quality attributes. J. Amer. Soc. Hort. Sci. 115: 779-783.

Ke, D., L. Rodríguez-Sinaloa, and A.A. Kader. 1991. Physiology and prediction of fruit tolerance to low-oxygen. J. Amer. Soc. Hort. Sci. 116:253-260.

Kevers, C., M. Falkowski, J. Tabart, J.O. Defraigne, J. Dommes, and J. Pincemail. 2007. Evolution of antioxidant capacity during storage of selected fruits and vegetables. J. Agr. Food Chem. 55:8596-9603.

Lee, K. and A.A. Kader. 2000. Preharvest and postharvest factors influencing vitamin $\mathrm{C}$ content of horticultural crops. Postharvest Biol. Technol. 20:207-220.

Martínez-Jávega, J.M., M.A. del Río, J. Cuquerella, and P. Navarro. 1998. Avances y perspectivas del empleo del frío como tratamiento cuarentenario en tránsito para cítricos. Memorias Seminario Internacional de Tecnología Postcosecha de Frutas y Hortalizas, CYTED, San Carlos, Cojedes, Venezuela, p. 9.

Miller, E.V. and A.S. Heilman. 1952. Ascorbic acid and physiological breakdown in the fruits of the pineapple (Ananas comosus L. Merr.). Science 116:505-506.

Mitcham, E.J., L. Tunya, A. Martin, Z. Shijun, and A.A. Kader. 2003. Summary of CA for arthropod control on fresh horticultural perishables. Acta Hort. 600:741-745.

Mulas, M. and M. Schirra. 2007. The effect of heat conditioning treatments on the postharvest quality of horticultural crops. Stewart Postharv. Rev. 3:1-6.
Nogata, Y., K. Sakamoto, H. Shiratsuchi, T. Ishii, M. Yano, and H. Ohta. 2006. Flavonoid Composition of fruit tissues of citrus species. Biosci. Biotechnol. Biochem. 70:178-192.

Nunes, C., J. Usall, T. Manso, R. Torres, M. Olmo, and J.M. Garcia. 2007. Effect of high temperature treatments on growth of Penicillium spp. and their development on 'Valencia' oranges. Food Sci. Technol. Int. 13:63-68.

Palma, A., S. D'Aquino, M. Agabbio, and S. Schirra. 2005. Changes in flavonoids, ascorbic acid, polyphenol content and antioxidant activity in cold-stored 'Fortune'. Mandarin. Acta Hort. 682:617-622.

Palou, L., J.A. Jacas, A. Marcilla, M. Alonso, and M.A. del Río. 2008a. Physico-chemical and sensory quality of 'Clemenules' mandarins and survival of the Mediterranean fruit fly as affected by complementary cold and carbon dioxide quarantine treatments. Postharvest Biol. Technol. 48:443-450.

Palou, L., C. Montesinos-Herrero, and M.A. del Río. 2008b. Short-term $\mathrm{CO}_{2}$ exposure at curing temperature to control postharvest green mold of mandarins. Acta Hort. 768:257-263.

Patil, B.S., J. Vanamala, and G. Hallman. 2004 Irradiation and storage influence on bioactive components and quality of early and late season 'Rio Red' grapefruit (Citrus paradisi Macf.). Postharvest Biol. Technol. 34:53-64.

Pesis, E. and I. Avissar. 1989. The post-harvest quality of orange fruits as affected by prestorage treatments with acetaldehyde vapour or anaerobic conditions. J. Hort. Sci. 118:481485.

Plaza, P., J. Usall, R. Torres, N. Lamarca, A. Asensio, and I. Viñas. 2003. Control of green and blue mould by curing of oranges during ambient and cold storage. Postharvest Biol. Technol. 28:195-198.

Porat, R., D. Pavoncello, J. Peretz, S. BenYehoshua, and S. Lurie. 2000. Effects of various heat treatments on the induction of cold tolerance and on the postharvest qualities of 'Star Ruby' grapefruit. Postharvest Biol. Technol. 18:159-165.

Rapisarda, P., M. Lo Bianco, P. Pannuzzo, and N. Timpanaro. 2008. Effect of cold storage on vitamin $\mathrm{C}$, phenolics and antioxidant activity of five orange genotypes [Citrus sinensis (L.) Osbeck]. Postharvest Biol. Technol. 49:348354.

Sánchez-Moreno, C., L. Plaza, B. de Ancos, and M.P. Cano. 2003. Quantitative bioactive compounds assessment and their relative contribution to the antioxidant capacity of commercial orange juice. J. Food Sci. Agr. 83:430-439.

Sánchez-Mata, M.C., M. Camara-Hurtado, C. Diez-Marques, and M.E. Torija-Isasa. 2000. Comparison of high-performance liquid chromatography and spectrofluorimetry for vitamin $\mathrm{C}$ analysis of green beans (Phaseolus vulgaris L.). Eur. Food Res. Technol. 210:220-225.

USDA. 2002. Importation of clementines from Spain: Final rule. United States Department of Agriculture. Fed. Regist. 67:64701-64739.

Vincent, C., G. Hallman, B. Panneton, and F. Fleurat-Lessard. 2003. Management of agricultural insects with physical control methods. Annu. Rev. Entomol. 48:261-281.

White, I.M. and M.M. Elson. 2004. Fruit files of economic significance: Their identification and bionomics. CAB International, The Australian Center for International Agricultural Research, Eastbourne, UK. 